\title{
Role of intravenous amino acid infusion in cases of oligohydramnios and its effect on amniotic fluid index and fetal weight gain
}

\author{
Pragya Shree*, Nupur Mittal, Vaibhav Kanti, Sonia Vishwakarma
}

\begin{abstract}
Department of Obstetrics and Gynaecology, Uttar Pradesh University of Medical Sciences, Saifai, Etawah - 206130, UP, India
\end{abstract}

Received: 23 June 2016

Accepted: 12 July 2016

*Correspondence:

Dr. Pragya Shree,

E-mail: pulkeshpragya@gmail.com

Copyright: () the author(s), publisher and licensee Medip Academy. This is an open-access article distributed under the terms of the Creative Commons Attribution Non-Commercial License, which permits unrestricted non-commercial use, distribution, and reproduction in any medium, provided the original work is properly cited.

\begin{abstract}
Background: Oligohydramnios in early pregnancy is attended by serious consequences to the fetus. Various conditions associated with oligohydramnios increase perinatal mortality and morbidity. Different medical and interventional methods have been tried to treat oligohydramnios. The present study was done to study the effect of intravenous amino acid infusion on amniotic fluid index (A.F.I) and fetal weight gain.

Methods: A total of 100 patients of oligohydramnios were studied. They were divided equally into study group and control group of 50 patients each by random allocation. The patients in the study group were given intravenous infusion of $200 \mathrm{ml}$ of amino acid on alternate day for one week while those in the control group were not given any intervention. Both the groups were monitored for change in A.F.I and fetal weight gain by ultrasound at the end of the week.

Results: The average gain in A.F.I in the study group $(2.57 \pm 0.68 \mathrm{~cm})$ was more than in the control group $(2.13 \pm$ $0.84 \mathrm{~cm}$ ). The average gain in fetal weight in the study group was 150.0 grams with SD of \pm 37.8 grams while in the control group it was 82.14 grams with SD of \pm 67.1 grams.

Conclusions: Thus intravenous infusion of amino acids increases short term A.F.I and also improves fetal weight and thus has a beneficial effect to both mother and fetus in case of oligohydramnios in developing countries. However, larger studies with controlled trial are needed to be done.
\end{abstract}

Keywords: Oligohydramnios, Intrauterine growth restriction, Amniotic fluid index

\section{INTRODUCTION}

Amniotic fluid which surrounds developing fetus in amniotic sac provides several benefits to the fetus. Despite decades of investigations, the regulation of amniotic fluid volume and composition remains incompletely understood. This results in part from the complexities inherent in the amniotic fluid dynamics, an enigmatic interaction of several sites of amniotic fluid secretion and excretion. ${ }^{1}$ Amnion is metabolically active, and is involved in solute and water transport to maintain amniotic fluid homeostasis and produces a variety of bioactive compounds like vasoactive peptides, growth factors and cytokines. ${ }^{1}$ Thus, amnion modulates chorionic vessel tone and blood flow. ${ }^{2}$ The mechanism of amniotic fluid production, consumption, composition and volume depends on the gestational age., During the first trimester the major source of amniotic fluid is from the maternal blood within the uterine wall and secretion from amnion. $^{2,3}$ In late first trimester and early second trimester, fetus and placenta differentiate and other pathways for amniotic fluid production and consumption come into play. ${ }^{2,3}$ Finally hormones like cortisol, antidiuretic hormone $(\mathrm{ADH})$ and prolactin also play a role in amniotic fluid regulation. ${ }^{2,3}$ There is a strong correlation between maternal plasma volume and amniotic fluid volume. $^{3,4}$ So elevated maternal plasma volume is associated with polyhydramnios and decreased plasma 
volume with oligohydramnios. ${ }^{2}$ Amniotic fluid volume increases progressively during gestation until approximately 32 weeks. ${ }^{4}$ From 32 to 39 weeks, the mean amniotic fluid volume is relatively constant in the range of 700 to $800 \mathrm{ml}^{4}$ From 40 to 44 weeks, there is progressive decrease in the amniotic fluid volume at a rate of $8 \%$ per week averaging only $400 \mathrm{ml}$ at 42 weeks. ${ }^{4}$ An amniotic fluid volume more than two standard deviation below the mean for specific gestational age or volume reduced below the $5^{\text {th }}$ percentile for particular gestational age would define oligohydramnios. ${ }^{5}$ Based on this definition a volume less than $300 \mathrm{ml}$ at term would constitute oligohydramnios. ${ }^{5}$

In 1987 a semi quantitative sonographic assessment of amniotic fluid volume (AFV) was developed known as Amniotic fluid index (AFI). ${ }^{6}$ This involves the summing of maximum vertical pockets in each of the four quadrants of the uterus. ${ }^{6,7}$ The original study conducted on 197 patients from 12 to 42 week's period of gestation indicated that the mean amniotic fluid index increased from $7 \mathrm{~cm}$ to $20 \mathrm{~cm}$ until 20 weeks, and then plateaued at approximately $16 \mathrm{~cm}$ for the remainder of the gestation. ${ }^{6-8}$ The likelihood of AFI $\leq 5 \mathrm{~cm}$ between 36-40 weeks of gestation is $2.4 \%$ and in pregnancies more than 40 weeks the incidence may be more than $12 \%$ as the amniotic fluid volume declines progressively after 41 weeks of gestation. $^{6-8}$ Amniotic fluid index remains the best Ultrasonographic method of estimation of amniotic fluid compared to other techniques. $^{7}$

Table 1: Diagnostic criteria for AFI (Jeng et al. 1992). ${ }^{9}$

\begin{tabular}{|ll|}
\hline AF volume & AFI values \\
\hline Oligohydramnios & $\leq 5 \mathrm{~cm}$ \\
\hline $\begin{array}{l}\text { Boarderline } \\
\text { oligohydramnios }\end{array}$ & $5.1-8 \mathrm{~cm}$ \\
\hline Normal & Normal $8.1-24 \mathrm{~cm}$ \\
\hline Polyhydramnios & $>24 \mathrm{~cm}$ \\
\hline
\end{tabular}

It was noted that pregnancies with an AFI $\leq 8 \mathrm{~cm}$ had higher incidence of meconium staining, cesarean section for fetal distress, abnormal fetal heart rate tracings and APGAR scores $\leq 7$ at 1 min. ${ }^{7,9}$ The various conditions associated with oligohydramnios are chromosomal abnormalities, uteroplacental insufficiency, congenital anomalies, pregnancy induced hypertension (P.I.H), intrauterine growth restriction (I.U.G.R), diabetes mellitus and post term pregnancy. ${ }^{10}$ Fetal abnormalities particularly involving the urinary tract are an important cause of early onset oligohydramnios. ${ }^{10}$

Alterations in fetal nutrition and endocrine status may result in developmental adaptations that permanently change the structure, physiology, metabolism, and postnatal growth of the offspring. ${ }^{11,12}$ Impaired placental synthesis of nitric oxide (a major vasodilator and angiogenic factor) and polyamines (key regulators of DNA and protein synthesis) may provide a unified explanation for the etiology of IUGR in response to maternal under nutrition and over nutrition. ${ }^{11,13,14}$ There is growing evidence that maternal nutritional status can alter the epigenetic state (stable alterations of gene expression through DNA methylation and histone modifications) of the fetal genome. ${ }^{12,15,16}$ This may provide a molecular mechanism for the role of maternal nutrition on the fetus. ${ }^{12,15,16}$ Thus under nutrition of various nutrients as amino acids, carbohydrates, essential fatty acids play a great role in the development of IUGR. ${ }^{15,16}$ Globally various trails have been done to explore the possibility of increasing the liquor amount and fetal weight by giving intravenous fluids of variety in the form of dextrose, maltose, amino acids etc. Improved maternal nutritional status by intravenous amino acid infusion appears to improve the AFI. ${ }^{16}$ This improvement may not have been achieved with diet alone because of non-compliance and socioeconomic status. ${ }^{12-14}$

\section{METHODS}

A total of 100 patients of oligohydramnios attending the outpatient department and emergency department of Obstetrics and Gynaecology were studied in this randomized control trial. They were divided equally into study group and control group of 50 patients each by random allocation. This study was done from August 2013 to April 2015.

This study consists of an analysis of effect of intravenous amino acid infusion in 50 cases with diagnosis of oligohydramnios by ultrasound between $24-34$ completed weeks of gestation on amniotic fluid index (A.F.I) and fetal weight gain compared with 50 controls with oligohydramnios without any intervention and matched for other variables like age, gestational age and any pregnancy complication.

\section{Inclusion criteria}

- Pregnant women with 24 - 34 weeks of gestational age.

- Amniotic fluid index of $\leq 8 \mathrm{~cm}$.

- Intact membranes.

- Patients without true labour pains.

- Oligohydramnios with and without medical complications like Diabetes mellitus, Pregnancy induced hypertension, Anaemia, Chronic nephritis, Cardiac disease.

\section{Exclusion criteria}

- Gestational age less than 24 and more than 34 completed weeks.

- Associated fetal malformations.

- Ruptured membranes.

For all the selected cases and controls, thorough history was taken and complete clinical examination was done. 
Clinical evidence of oligohydramnios was looked for. The previous obstetric records and ultrasound reports were reviewed.

Only those women with previous regular cycles who remembered their date of last menstrual period correctly and the gestational age calculated by clinical examination corresponded with ultrasound examination were taken for study. During this period the A.F.I is at a plateaued level. A.F.I level of $<8 \mathrm{~cm}$ was considered as oligohydramnios as according to study conducted by Jeng et al. ${ }^{9}$ For all the women, ultrasound examination was done and amniotic fluid index was calculated by four quadrant amniotic fluid volume measurement technique. Fetal weight was also measured. Routine blood and urine investigations were done.

The patients in the study group were given intravenous infusion of $200 \mathrm{ml}$ of amino acid on alternate day for one week while those in the control group were not given any intervention. Both the groups were monitored for change in amniotic fluid index and fetal weight gain by ultrasound at the end of the week. Market available amino-acid infusion solution in the study was a total amino-acid infusion solution containing essential and non-essential amino-acid in a balanced ratio, as per evaluation method for protein nutrition proposed by FAO/WHO joint special committee.

The results were recorded and tabulated. Descriptive data are presented as number and percentages with average (mean) and standard deviation wherever required. Chisquare test was used for analysing categorical data. Student's test was used for comparing mean between two groups. A p - value of 0.05 or less was considered statistically significant.

\section{RESULTS}

A total of 100 cases of oligohydramnios were studied with respect to incidence of oligohydramnios, distribution of oligohydramnios, gestational age and maternal age relation to oligohydramnios, parity distribution, antenatal complication associated with oligohydramnios and effect of amino acid infusion on AFI and fetal weight gain.

The average maternal age in the study group was 23.12 years with SD of \pm 8.3 years and in the control group was 22.4 years with SD of \pm 11.9 years. The mean maternal age of the study group was greater than those in the control group but the difference was not statistically significant as determined by Chi - square analysis. The average gestational age in both the groups was 30 weeks. Majority of the patients both in the study group and control group were either primigravida or fifth gravida. In study group $32 \%$ patients and in control group $30 \%$ patients were nulliparous. In the study group $33(66 \%)$ patients had borderline oligohydramnios (A.F.I $5-8 \mathrm{~cm}$ ) while $17(34 \%)$ patients had severe oligohydramnios (A.F.I $<5 \mathrm{~cm})$ whereas in the control group $40(80 \%)$ patients had borderline oligohydramnios and 10 (20\%) patients had severe oligohydramnios.

Table 1: Demographic profile of patients.

\begin{tabular}{|c|c|c|c|c|}
\hline & & $\begin{array}{l}\text { Study } \\
\text { group }\end{array}$ & $\begin{array}{l}\text { Control } \\
\text { group }\end{array}$ & Significance \\
\hline \multicolumn{2}{|c|}{ Mean Maternal Age } & $\begin{array}{l}23.12 \\
\pm 8.3 \\
\text { years }\end{array}$ & $\begin{array}{l}22.4 \pm \\
11.9 \\
\text { years }\end{array}$ & $\begin{array}{l}\mathrm{p}>0.05 \text { (No } \\
\text { significant } \\
\text { difference) }\end{array}$ \\
\hline \multicolumn{2}{|c|}{$\begin{array}{l}\text { Average Gestational } \\
\text { Age }\end{array}$} & $\begin{array}{l}30 \\
\text { weeks }\end{array}$ & $\begin{array}{l}30 \\
\text { weeks }\end{array}$ & $\begin{array}{l}\text { No } \\
\text { significant } \\
\text { difference }\end{array}$ \\
\hline \multirow{3}{*}{$\begin{array}{l}\text { Distribution } \\
\text { of } \\
\text { complications }\end{array}$} & P.I.H & $37.5 \%$ & $41.2 \%$ & $\begin{array}{l}\mathrm{p}>0.05 \text { (No } \\
\text { significant } \\
\text { difference) }\end{array}$ \\
\hline & A.P.H & $25 \%$ & $23.5 \%$ & $\begin{array}{l}\mathrm{p}>0.05 \text { (No } \\
\text { significant } \\
\text { difference) }\end{array}$ \\
\hline & I.U.G.R & $37.5 \%$ & $35.3 \%$ & $\begin{array}{l}\mathrm{p}>0.05 \text { (No } \\
\text { significant } \\
\text { difference) }\end{array}$ \\
\hline
\end{tabular}

Table 2: Gravidity distribution.

\begin{tabular}{|lcccccc|}
\hline Gravidity & $\mathrm{G}-1$ & $\mathrm{G}-2$ & $\mathrm{G}-3$ & $\mathrm{G}-4$ & $\mathrm{G}-5$ & Total \\
\hline $\begin{array}{l}\text { Study } \\
\text { group }\end{array}$ & 16 & 8 & 5 & 8 & 13 & 50 \\
\hline $\begin{array}{l}\text { Control } \\
\text { group }\end{array}$ & 15 & 8 & 7 & 9 & 11 & 50 \\
\hline
\end{tabular}

Antenatal complications were associated with $64 \%$ of the study group and $68 \%$ of the control group while the rest had isolated oligohydramnios. The complications associated with oligohydramnios i.e. PIH, APH, IUGR, etc. was equally distributed among the study group and control group and there was no statistically significant difference in their distribution in both the groups. This implies that both the study and control group were similar and comparable with respect to complications. In this study the most common complications were PIH and IUGR.

The average A.F.I in the study group was $5.56 \mathrm{~cm}$ with $\mathrm{SD}$ of $\pm 2.3 \mathrm{~cm}$ and in the control group was $6.32 \mathrm{~cm}$ with $\mathrm{SD}$ of $\pm 4.6 \mathrm{~cm}$. The average A.F.I of the control group was greater than in the study group but the difference was not statistically significant as derived from the student $\mathrm{t}-$ test $(\mathrm{t}=1.05, \mathrm{p}$ value $>0.05)$. The average gain in A.F.I in the study group $(2.57 \pm 0.68 \mathrm{~cm})$ was more than in the control group $(2.13 \pm 0.84 \mathrm{~cm})$ and the difference was statistically significant $(t=2.44$, $\mathrm{p}$ value $<0.05)$.

The average fetal weight of the study group was 1020 grams with SD of \pm 117.4 grams and that of the control group was 1054 grams with SD of \pm 128.1 grams but the difference between the two was statistically not significant. The average gain in fetal weight in the study group was 150.0 grams with $\mathrm{SD}$ of \pm 37.8 grams while that in the control group was 82.14 grams with SD of \pm 
67.1 grams. Applying $\mathrm{t}-$ test for statistical analysis it was clear that the gain in fetal weight in the study group was significantly greater than those in the control group.

Table 3: A.F.I and fetal weight gain.

\begin{tabular}{|lll|l|}
\hline & $\begin{array}{l}\text { Study } \\
\text { group }\end{array}$ & $\begin{array}{l}\text { Control } \\
\text { group }\end{array}$ & Significance \\
\hline $\begin{array}{l}\text { Average } \\
\text { A.F.I }\end{array}$ & $\begin{array}{l}5.56 \pm 2.3 \\
\mathrm{~cm}\end{array}$ & $\begin{array}{l}6.32 \pm 4.6 \\
\mathrm{~cm}\end{array}$ & $\begin{array}{l}\mathrm{p}>0.05 \text { (No } \\
\text { significant } \\
\text { difference) }\end{array}$ \\
\hline $\begin{array}{l}\text { Average } \\
\text { gain in } \\
\text { A.F.I }\end{array}$ & $\begin{array}{l}2.57 \pm 0.68 \\
\mathrm{~cm}\end{array}$ & $\begin{array}{l}2.13 \pm 0.84 \\
\mathrm{~cm}\end{array}$ & $\begin{array}{l}\mathrm{p}<0.05 \\
\text { (Significant } \\
\text { difference) }\end{array}$ \\
\hline $\begin{array}{l}\text { Average } \\
\text { fetal weight }\end{array}$ & $117.4 \mathrm{gm}$ & $128.1 \mathrm{gm}$ & $\begin{array}{l}\text { significant } \\
\text { difference) }\end{array}$ \\
\hline $\begin{array}{l}\text { Average } \\
\text { fetal weight } \\
\text { gain }\end{array}$ & $\begin{array}{l}150 \pm 37.8 \\
\mathrm{gm}\end{array}$ & $\begin{array}{l}82.14 \pm \\
67.1 \mathrm{gm}\end{array}$ & $\begin{array}{l}\mathrm{p}<0.01 \\
\text { (Significant } \\
\text { difference) }\end{array}$ \\
\hline
\end{tabular}

\section{DISCUSSION}

In the present study maximum number of cases in both study and control group were in the age group of 20 to 25 years, as compared to other age groups, reflecting the child bearing age of most of the women with the average maternal age of $23.12 \pm 8.3$ years in the study group and $22.4 \pm 11.9$ years in the control group. Similar studies by Chauhan $\mathrm{P}$ et al, Jun Zhang et al and Everett $\mathrm{F}$ et al found that the mean maternal age were $23.6 \pm 6.5$ years, $28.4 \pm$ 3.4 years and $23.8 \pm 5.7$ years respectively. ${ }^{17-19}$ Shivkumar PV et al in their study found that $78 \%$ cases were in the age group of 20-29 years with a mean maternal age of $22.8 \pm 4.2$ years. $^{16}$

The mean gestational age in the present study was 30.0 weeks. Similar studies by Jun Zhang et al, Casey B et al, Everett $\mathrm{F}$ et al and Hoskins IA et al found that, the mean gestational age were $38.1 \pm 3.3$ weeks, $37.5 \pm 2$ weeks, $34.3 \pm 2.1$ weeks, and (mean $\pm \mathrm{SD}$ ) was $36.3 \pm 2$ weeks respectively. ${ }^{18-21}$

Obstetrical complications frequently associated with oligohydramnios were pregnancy induced hypertension (PIH), postdated pregnancy, intrauterine growth restriction, fetal renal anomalies, prematurity and intrauterine death of the fetus. Hypertensive disorders which cause chronic placental insufficiency lead to oligohydramnios. In the present study $64 \%$ in the study group and $68 \%$ in the control group had associated obstetrical complications; acting singly or in combination for causing oligohydramnios. PIH was present in $24 \%$ of the cases and $28 \%$ of the control. Golan A et al in his study found maternal hypertension in $22.1 \%$ cases. $^{22}$ Chandra $\mathrm{P}$ et al and Sriya $\mathrm{R}$ et al. found $38.46 \%$ and $31 \%$ of hypertensive disorders in their cases respectively.
Mercer L J et al found that preeclampsia was present in $24.7 \%$ of cases with decreased fluid. ${ }^{23}$ Study by Chauhan $\mathrm{P}$ et al reported preeclampsia in $12 \%$ cases. ${ }^{17}$ They concluded that the incidence of oligohydramnios ranges from 10 to $30 \%$ in hypertensive patients requiring hospitalization. In the present study, intra uterine growth restriction was present in $24 \%$ in both study and control groups. Shivkumar PV et al in their study found the incidence of IUGR in $20 \%$ cases. $^{16}$

We found that there was significant difference in the improvement of AFI in the groups who received fluids and amino acids as compared to the control group as seen by USG after a week. There was an average A.F.I gain of $2.57 \pm 0.68 \mathrm{~cm}$ which was significantly greater than those in the control group $(\mathrm{t}=2.44, \mathrm{p}$ value $<0.05)$. In our study the average gain in fetal weight in the study group was $150.0 \pm 37.8$ grams which was significantly greater than those in the control group in which it was only 82.14 $\pm 67.1 \mathrm{gm}$. Mesaki and Cetin et al also concluded from their study that $10 \%$ Dextrose and $12 \%$ amino acid increases fetal weight effectively. ${ }^{15}$ Tayade $\mathrm{S}$ et al in their study on the role of intravenous hydration and amino acid infusion in intrauterine growth restriction and oligohydramnios concluded that fetal weight gain of more than 500 grams was seen more significantly in group 2 and 3 who were receiving amino acids proving that it not only increases AFI but also increases foetal weight which is the need of present hour to reduce perinatal mortality indirectly. ${ }^{14,16}$ Lampariello $\mathrm{C}$ et al administered L - Arginine to 43 pregnant women whose fetuses had been diagnosed with fetal growth restriction by ultrasonic examination and by Doppler evaluation of velocimetry value. ${ }^{25}$ As a result the clinical course of pregnancy was improved in 32 women and 19 cases of fetal growth restriction were reversed.

\section{CONCLUSION}

An amniotic fluid index of $\leq 5 \mathrm{~cm}$ detected between 24 34 weeks of gestation is an indicator of intrauterine growth restriction and poor perinatal outcome. Thus intravenous infusion of amino acids if given as a week regimen on alternate days increases short term AFI and also improves foetal weight and thus has a beneficial effect to both mother and foetus in case of oligohydramnios in developing countries. However, larger studies with controlled trial are needed to be done. Further studies are needed to elucidate the role of the placenta in amino acids supply to the foetus and its relationships to fetal growth. In the meantime, IUGR infants could be considered for amino acid \& other supplementations to restore a physiologic composition of their body pools.

\section{ACKNOWLEDGEMENTS}

I take this opportunity with much pleasure to thank all the people who have helped me through the course of my journey towards producing this work. I sincerely thank all 
my teachers and colleagues for their guidance, help and motivation. I gratefully acknowledge them for their advice, supervision, and crucial contribution. I take this opportunity to express my heartiest thanks and regards to Dr. B. B. Maheshwari, Ex. Professor, Department of Social and Preventive Medicine, S. N. Medical College, Agra, for his valuable and timely guidance and cooperation in doing statistical analysis to complete my work.

\section{Funding: No funding sources}

Conflict of interest: None declared

Ethical approval: The study was approved by the Institutional Ethics Committee

\section{REFERENCES}

1. Cunnigham FG, Gant NF, Leveno KJ, Gilstrap LC, Hauth JC, Wenstrom KD. Placenta and fetal membranes. In: Text book of Williams obstetrics, 21th ed. McGraw-Hill Company. 2003. Pp. 101-103.

2. Brace RA, Wolf EJ. Normal amniotic fluid volume changes throughout pregnancy. Am J Obstet gynecol. 1989;161:382-8.

3. Brace RA. Physiology of amniotic fluid volume regulation. Clin Obstetrics and Gynaecol. LippincotRaven publication. 1997;40(2):280-9.

4. Arias Fernando. Practical guide to high risk pregnancy and delivery. 2nd ed. Mosby - year Book. Inc. 1993;30-20:150-9.

5. Callen. Amniotic fluid: Its role in fetal health and disease. In: Textbook of ultrasonography in obstetrics and gynaecology. 14th ed. W.B. Saunders Company. 2000. Pp. 638-659.

6. Phelan JP, Smith CV, Broussard P. The four quadrant assessment of amniotic fluid volume at 3642 wks gestation. J Reprod Med. 1986;32:540.

7. Moore TR, Cayle JE. The amniotic fluid index in normal human pregnancy. Am J Obstet Gynecol. 1990;162:1168.

8. Rutherford SE, Phelan JP, Smith CV, Jacobs N. The four quadrant assessment of amniotic fluid volume: An adjunct to antepartum fetal heart rate testing. Obstet Gynecol. 1987;70:353.

9. Jeng CJ, Lee JF, Wang KG. Decreased amniotic fluid index in term pregnancies - clinical significance. J Repro Med. 1992;37:789-92.

10. Cunningham FC, Gant NF, Leveno KJ, Gilstrap LC, Hauth JC, Wenstrom KD. Abnormalities of the fetal membranes and amniotic fluid. In: Textbook of Williams Obstetrics, 21st ed. Mc Graw Hill Compan. 2003. Pp. 821-822.

11. Kilpatrick SJ, Safford K, Pomeroy T, et al: Maternal hydration affects amniotic fluid index (AFI). Am J Obstet Gynecol. 1991;164:361.

12. Suzuki S, Mine K, Sawa R, Yoneyama Y, Araki T. 10\% Maltose Infusion Therapy for Oligohydramnios. Australian and New Zealand Journal of Obstetrics and Gynaecology. 1991;39:373-5.
13. Abida Ahmad J K. Intravenous aminoacid therapy in Oligohydramnios; Practitioner. 2006;13(3):140-1.

14. Umber A, Chohan MA . J Coll Physicians Surg Pak. 2007;17(6):336-9.

15. Mesaki Cetin I, Corbetta C, Piceni Sereni L, Marconi AM, Bozzetti P, Pardi G. concentration s and fetal - maternal concentration differences of plasma amino acids in normal and intrauterine growth retarded (IUGR) pregnancies. Am J Obstet Gynecol. 1996;174:1575-83.

16. Shivkumar PV, Tayade S, Tayade AT, Bagde ND, Bagde MN. The Role of Intravenous Hydration and Amino Infusion in Intrauterine Growth Restriction and Oligohydramnios. Int $\mathrm{J}$ Biol Med Res. 2011;2(4):1078-83.

17. Chauhan SP, Hendrix NW: Intrapartum oligohydramnios does not predict adverse peripartum outcome among high risk parturient. Am J Obstet Gynecol. 1997;176(6):1130-6.

18. Jun Zhang, James Troendle: Isolated oligohydramnios is not associated with adverse perinatal outcome. Int $\mathrm{J}$ Gynaecol Obstet. 2004;3:220-5.

19. Everett FM, Thomas EN: Measurement of amniotic fluid volume-Accuracy of ultrasonography technique. Am J Obstet Gynecol. 1992;167:1533-7.

20. Casey Brian M, Donald D McIntire: Pregnancy outcomes after antepartum diagnosis of oligohydramnios at or beyond 34 weeks' gestation. Am J Obstet Gynecol. 2000;182(4):909-12.

21. Hoskins IA, Friden FJ. Variable deceleration in reactive non stress test with decreased amniotic fluid index predicts fetal compromises. Am J Obstet Gynecol. 1991;165(4):1094-8.

22. Golan A, Lin G. Oligohydramnios - maternal complications and fetal outcome in 145 cases. Gynecol Obstet Invest. 1994;37(2):91-5.

23. Mercer Lane, L.G. Brown: A survey of pregnancies complicated by decreased amniotic fluid. Am J Obstet Gynecol. 1984;149:355-61.

24. Tayade S. The significance of meconium stained amniotic fluid - A cross sectional study in rural set up. I J BAR. 2012;3:12.

25. Lampariello C, De Blasio A, Merenda A, Graziano E, Michalopoulou A, Bruno P. Use of L-arginine in intrauterine growth retardation (IUGR): Authors' experience. Minerva Ginecol. 1997;49:577-81.

26. Moore TR, Longo J, Leopald GR, Casola G, Gosink $\mathrm{BB}$. The reliability and predictive value of an amniotic fluid scoring system in severe second trimester oligohydramnios. Obstet Gynecol. 1989;73:739.

27. Goldstein RB, Filly RA. Sonographic estimation of amniotic fluid volume, subjective assessment versus pocket measurements. J ultrasound Med, 1988;7:363.

28. Hill LM. Oligohydramnios: Sonographic diagnosis and clinical implication. In clinical bstetrics and gynecology. Pitkin Roy M, Scot James R. Philadelphia: lippincot - Raven Publication. 1997;40(2):314-27. 
29. Clement D, Barry MD: Acute oligohydramnios in postdate pregnancy. Am J Obstet Gynecol 1987; 157:884-6.

30. Browen-Chatoor JS, Kulkarni SK: Amniotic fluid index in the management of postdates pregnancy. West Indian Med J. 1995;44(2):64-6.
Cite this article as: Shree P, Mittal N, Kanti V, Vishwakarma S. Role of intravenous amino acid infusion in cases of oligohydramnios and its effect on amniotic fluid index and fetal weight gain. Int $\mathbf{J}$ Reprod Contracept Obstet Gynecol 2016;5:2804-9. 